\title{
Patients with Laron syndrome are protected from development of cancer even if treated with IGF-I
}

\author{
Laron Zvi \\ Rachel Steuerman \\ Shevah Orit \\ Kauli Rivka
}

Endocrinology \& Diabetes Research Unit, Schneider Children's Medical Center, Sackler School of Medicine, Tel-Aviv University, Israel

\author{
Address for correspondence: \\ Laron Zvi \\ Endocrinology \& Diabetes Research Unit \\ Schneider Children's Medical Center \\ Sackler School of Medicine \\ Tel-Aviv University, Israel \\ E-mail: laronz@clalit.org.il
}

\section{Summary}

In accordance with the link between increased GH and IGF-I secretion and cancer, we found that homozygous patients with Laron syndrome (severe GH insensitivity) and low to undetectable serum IGF-I are protected from developing cancer even if treated with IGF-I to enhance linear growth.

KEY WORDS: Laron syndrome; GH receptor; IGF-I and cancer; $\mathrm{GH}$ insensitivity; cancer.

\section{Introduction}

Cancer cells are characterized by their capacity for self-sufficient proliferation, refractoriness to growth inhibitory signals, resistance to apoptosis and capacity to recruit angiogenesis (1). The causes of cancer include genetic predisposition, gene-environment interactions and infections agents. Among the risk factors are hormones including pituitary growth hormone $(\mathrm{GH})$ and insulin like growth factor I (IGF-I) (2-4). In 1966 we described a new disease resembling congenital isolated GH deficiency (c1GHD) (5) but which surprisingly was found to be characterized by high serum levels of $\mathrm{GH}$ and low to undetectable levels of IGF-I (6). The patients originated from the Middle East and most belonged to consanguineous families (7). Subsequently more patients were diagnosed in various parts of the world (5), and the disease was coined by William Daughaday Laron type dwarfism, and changed subsequently to Laron syndrome (LS, OMIM\#262500). In
1983 we showed that liver membranes of LS patients could not bind $125 \mathrm{I}-\mathrm{hGH}$ explaining the etiology of this disease as insensitivity (resistance) to $\mathrm{GH}(8)$, subsequently we and others demonstrated that the resistance to $\mathrm{GH}$ was due to deletions (9) or mutations in the hGH receptor $(5,10)$.

\section{Aim of Study}

Having a population with an inability to generate IGF-I we considered it to be the right model to test, the relationship between IGF-I deficiency and cancer.

We hypothesized that if indeed GH/IGF-I promotes malignancy: patients with congenital IGF-I deficiency as exemplified by Laron syndrome should be cancer free.

\section{Subjects and Methods}

To test this hypothesis we analyzed the medical charts of our 68 LS patients, sent a questionnaire to medical clinics known to follow patients with LS and screened the medical literature for published patients (11-13). We were able to collect data on 234 patients with LS, adding recently 4 new patients to those included in the report by Steuerman et al. (14). Dr Guevara-Aguirre who follows 99 patients in Ecuador expressed the wish to analyze their patients separately (personal communication).

It is assumed that both groups together amounting to 334 patients represent about 2/3 of all Laron Syndrome patients in the world. Sixty-four patients in the pediatric age group had been treated with IGF-I for many years; so were 5 adult patients but only for one year $(5,7)$. We were also able to obtain data on 339 first and second degree relatives.

\section{Statistics}

The collected data were analyzed using the BMDP statistical software (14). One-way and two-way ANOVA were used to analyzed continuous variables (age) and as for discrete variables (diagnosis/type of malignancy). $X^{2}$ test and Fisher's exact test were used. A P value $<0.05$ was considered statistically significant.

\section{Results}

The study was performed in two stages: the first part performed during the years 2004-2006, led to the announce- 
ment of the preliminary and exciting results in 2005 at a cancer meeting in Taormina (15) namely that none of the LS patients had developed cancer their age ranging from 3-78 years with a mean age of 32.3 years in our cohort and 16 years in the US and European one. These findings in 169 patients with Laron syndrome and 250 relatives were published in 2007 (16). We continued to collect data to ascertain these findings and published the second stage early in the year 2011 (14). The study was updated until August 2013. Table 1, which also includes the findings of the Ecuadorian groups (17).

It is evident that none of the homozygous LS patients, many of them adults, even old, had developed any malignancy whereas their heterozygote $1^{\text {st }}$ degree relatives have.

Table 1. Prevalence of malignancies in Laron syndrome patients and their first degree relatives.

\begin{tabular}{llll}
\hline Subject & \multicolumn{3}{l}{ Malignancies } \\
\hline & $\mathrm{N}$ & $\mathrm{N}$ & $\%$ \\
Laron syndrome & 234 & 0 & 0 \\
$1^{\text {st }}$ degree relatives & 218 & 17 & 8.3 \\
\hline
\end{tabular}

\section{Discussion}

Our findings that homozygous patients with Laron syndrome are protected from developing cancer have been confirmed by Guevara-Aguirre et al. (17) who surveyed 99 patients with LS in Ecuador. One of their LS patients who developed ovarian carcinoma was a double heterozygote.

The mechanism which protects the patients with Laron syndrome is so far undetermined. Their $1^{\text {st }}$ degree heterozygote family members (parents and siblings) who are not protected from cancer do not resemble phenotypically LS patients $(6,7)$. The cause must be related to the fact that the heterozygote subjects produce active growth hormone and IGF-I. The conclusion is that only complete congenital absence of IGF-I induces a cancer protective mechanism.

We (18) and probably others (17) are taking on the challenge to solve the riddle which should lead not only to a better understanding of the link between IGF-I and cancer but hopefully to improved and novel treatment.

\section{References}

1. Hanahan D, Weinberg RA. The hallmarks of cancer. Cell 2000; 100:57-70.

2. Werner $\mathrm{H}$, Bruchim I. The insulin growth factor-1 receptor as an oncogene. Arch Phyiol Biochem 2009; 115:58-71.

3. Furstenberger G, Senn HJ. Insulin like growth factors and cancer. Lancet Oncology 2002; 3:298-302.

4. Frasca S, Pandini G, Sciacci L, Pezzino V, Squatrito
$S$, Belfiore A, Vigneri $R$. The role of insulin receptors and IGF-I receptors in cancer and other diseases. Arch Physiol Biochem 2008; 114:23-37.

5. Laron Z. Laron Syndrome (Primary Growth Hormone Resistance or Insensitivity): The Personal Experience 1958-2003. J Clin Endocrinol Metab 2004; 89:1031-1044.

6. Laron Z, Pertzelan A, Mannheimer S. Genetic pituitary dwarfism with high serum concentration of growth hormone. A new inborn error of metabolism? Isr J Med Sci 1966; 2:153-155.

7. Laron Z, Kopchick J. (Eds) Laron Syndrome from Man to Mouse. Springer Verlag, Heidelberg, Berlin 2011; pp 531.

8. Eshet R, Laron Z, Pertzelan A, Dintzman M. Defect of human growth hormone in the liver of two patients with Laron type dwarfism. Isr J Med Sci 1984; 20:8-11.

9. Godowski PJ, Leung DW, Meacham LR, Galgani JP, Helimiss R, Keret R, Rotwein PS, Parks JS, Laron Z, Wood WI. Characterization of the human growth hormone receptor gene and demonstration of a partial gene deletion in two patients with Laron type dwarfism. Proc Natl Acad Sci USA 1989; 86:80838087.

10. Shevah O, Laron Z. Genetic analysis of the pedigrees and molecular defects of the GH-receptor gene in the Israeli cohort of patients with Laron Syndrome. Pediatr Endocrinol Rev; 3(Suppl 3):489-497. Erratum Pediatr Endocrinol Rev 2007; 5:470.

11. Rosenfeld RG, Rosenbloom AL, Guevara-Aguirre J. Growth hormone (GH) insensitivity due to primary GH receptor deficiency. Endocr Rev 1994; 15:369-390.

12. Savage MO, Attie KM, David A, Metherell LA, Clark AJ, Camacho-Hübner C. Endocrine assessment, molecular characterization and treatment of growth hormone insensitivity disorders. Nat Clin Pract Endocrinol Metab 2006; 2:395-407.

13. Chernausek SD, Backeljauw PF, Frane J, Kuntze J, Underwood LE. GH Insensitivity Syndrome Collaborative Group Long-term treatment with recombinant insulin-like growth factor (IGF-I) in children with severe IGF-I deficiency due to growth hormone insensitivity. J Clin Endocrinol Metab 2007; 92:902910.

14. Steuerman R, Shevah O, Laron Z. Congenital IGFI deficiency tends to confer protection against postnatal development of malignancies. Eur J Endocrinol 2011; 164:485-489.

15. Shevah O, Laron Z. Patients with congenital deficiency of IGF-I seem protected from the development of malignancies: A preliminary report. Growth Hormone \& IGF Res 2007; 17:54-47.

16. Laron $Z$. The prevalence of malignancies in patients with congenital absence of IGF-I. Vigneri R. The Role of IGF System in Cancer Congress Taormina, Italy, Nov 10-12, 2005.

17. Guevara-Aguirre J, Balasubramanian $P$, GuevaraAguirre M, Wei M, Madia F, Cheng CW, Hwang D, Martin-Montalvo A, Saavedra J, Ingles S, de Cabo R, Cohen P, Longo VD. Growth hormone receptor defi- 


\section{Zvi et al.}

ciency is associated with a major reduction in pro-aging signaling, cancer and diabetes in humans. Sci Transl Med 2011; 3(70):doi:10.1126/scitranslmed.3001845.
18. Lapkina L, Laron Z, Werner H, Genome-wide analysis of cancer protection pathways in Laron Syndrome patients. Abstr\# P01-22. Growth Hormone \& IGF Research 2012; 22:S39. 